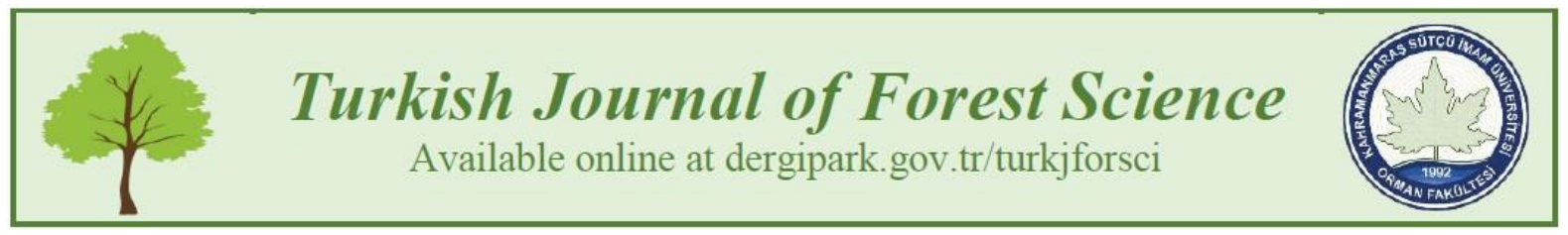

\title{
SPATIAL ANALYSES OF ASTRAGALUS SPECIES DISTRIBUTION AND RICHNESS IN KAHRAMANMARAŞ (TURKEY) BY GEOGRAPHICAL INFORMATION SYSTEMS (GIS)
}

\author{
Alper UZUN ${ }^{1, *}$, Seyran PALABAŞ UZUN ${ }^{1}$, Ali DURMAZ ${ }^{2}$ \\ ${ }^{1}$ Department of Forest Engineering, Faculty of Forestry, Kahramanmaraş Sütçü Imam University, \\ Kahramanmaraş / Turkey \\ ${ }^{2}$ Graduate School of Natural and Applied Sciences, Kahramanmaraş Sütçü Imam University, \\ Kahramanmaraş / Turkey \\ *Corresponding Author: auzun@ksu.edu.tr
}

Alper UZUN: https://orcid.org/0000-0002-2577-7460

Seyran Palabaş UZUN: https://orcid.org/0000-0001-7090-4804

Ali DURMAZ: https://orcid.org/0000-0001-5959-5510

Please cite this article as: Uzun, A., Uzun, S. P., \& Durmaz, A. (2019). Spatial analyses of Astragalus species distribution and richness in Kahramanmaraş (Turkey) by geographical information systems (GIS). Turkish Journal of Forest Science, 3(1), 37-59.

\section{ARTICLE INFO}

Research Article

Received 13 April 2019

Received in revised form 28 April 2019

Accepted 28 April 2019

Published online 29 April 2019

\begin{abstract}
The aim of this study is to determine the species richness of the genus Astragalus in Kahramanmaraş and to present the updated distribution information with the help of Geographic Information Systems in a conservation point of view. In this study, country flora, recently published articles on the province of Kahramanmaraş, checklists, regional flora studies in the province, section revisions of Astragalus and also the plant samples collected from the field surveys in Kahramanmaraş were used. According to the results of the field studies supported by the literature, 95 plant taxa belonging to the genus Astragalus are listed together with their valid names and previous synonyms. The number of endemic taxa in Kahramanmaraş is 37 (with the endemism rate 39\%). In the plant list, the largest sections of the genus Astragalus are Rhacophorus with 23 taxa, Onobrychoidei with 8 taxa, Dasyphyllium, Malacothrix, Myobroma, Proselius and Pterophorus with 6 taxa for each. The distribution of the taxa to the phytogeographical regions is as follows; 56 taxa $(59 \%)$ Irano-Turanian element, 28 taxa (30\%) Multi-regional or unknown origin, and the rest; 6 taxa $(6 \%)$ is an element of the Eastern Mediterranean, 4 taxa $(4 \%)$ of the Eastern Mediterranean (mountain) element and 1 taxon (1\%) of the Euro-Siberian element. IUCN threat categories of endemic taxa were reassessed. As a result, totally 11 taxa are in threatened categories according to IUCN (4 taxa in CR, 2 taxa in EN and 5 taxa in VU categories) and the remaining 26 taxa are in lower threat categories (NT and LR). According to the distributions of species, which produced based on the grid system and the conservation point of view; (J13) in Çağlayancerit, (D4, E4 and G8) in Göksun, (I10) in the place between Ekinözü and central district, and (K10) in the central district of Kahramanmaraş were determined as the richest squares. These areas are very important in terms of conservation
\end{abstract}


biology as they are the most intense areas of steppic conditions, livestock and grazing pressure.

Keywords: Spatial analyses, Richness, Astragalus, Geographical Information System, Kahramanmaraş, Turkey.

\title{
COĞRAFİ BİLGI SISTEMLERİ (CBS) İLE KAHRAMANMARAŞ'TA (TÜRKIYE) ASTRAGALUS TÜR DAĞILIMI VE ZENGINLIGGININ KONUMSAL ANALIZi
}

\author{
ESER BİLGISİ \\ Arastirma Makalesi \\ Geliş 13 Nisan 2019 \\ Duzeltmelerin gelişi 28 Nisan 2019 \\ Kabul 28 Nisan 2019 \\ Yayınlanma 29 Nisan 2019
}

ÖZET: $\mathrm{Bu}$ çalışmanın amacı, Kahramanmaraş'taki Astragalus cinsinin bitkisel tür çeşitliliğini tespit etmek ve koruma bakış açısıyla güncellenmiş dağılım bilgilerini Coğrafi Bilgi Sistemleri yardımı ile sunmaktır. Türkiye florası, Kahramanmaraş iline ilişkin yakın zamanda yayınlanan makaleler, kontrol listeleri, il içindeki bölgesel flora çalışmaları, seksiyon revizyonları ve ayrıca Astragalus cinsine ilişkin Kahramanmaraş doğasından bizim tarafımızdan toplanan ve herbaryum örneği haline getirilen bitki koleksiyonu kullanılmıştır. Literatür ile de desteklenen saha çalışmalarının sonuçlarına göre, Astragalus cinsine ait 95 bitki taksonu geçerli adları ve önceki eş isimleri ile birlikte listelenmiştir. Kahramanmaraş'taki endemik Astragalus takson sayısı 37'dir (endemizim oranı \%39). Bitki örtüsü içerisinde Astragalus cinsine ait en büyük seksiyonlar 23 taksonla Rhacophorus, 8 taksonla Onobrychoidei, 6'şar taksonla Dasyphyllium, Malacothrix, Myobroma, Proselius ve Pterophorus'dur. Kahramanmaraş için Astragalus cinsine ait taksonların fitocoğrafik bölgelere dağılımı şu şekildedir; 56 takson (\%59) İran-Turan elementi, 28 takson (\% 30) çok bölgeli veya orijini bilinmeyen ve geri kalanlar ise; 6 takson (\%6) Doğu Akdeniz elementi, 4 takson (\%4) Doğu Akdeniz (dağ) elementi ve 1 takson (\% 1) Avrupa-Sibirya elementidir. Endemik taksonların IUCN tehdit kategorileri belirlenmiştir. Sonuç olarak, IUCN'e göre toplam 11 takson tehdit altında kategorisinde (CR kategorisinde 4 takson, EN kategorisinde 2 takson ve VU kategorisinde 5 takson) yer alırken geriye kalan 26 takson daha düşük tehdit kategorilerindedir (NT ve LR). Karelaj sistemi ile oluşturulan tür dağılımlarına ve koruma bakış açısına göre, Çağlayancerit'te (J13) ve Göksun'da (D4, E4 ve G8) Ekinözü ve merkez ilçe arasında (I10) ve Kahramanmaraş Merkez ilçede (K10) takson sayısı bakımından en zengin kareler olarak belirlenmiştir. Bu alanlar step koşullarının, hayvancılık ve otlatma baskısının en yoğun olduğu bölgeler olması sebebiyle koruma biyolojisi açısından oldukça önemlidir.

Anahtar Kelimeler: Konumsal analiz, Zenginlik, Astragalus, Coğrafi Bilgi Sistemleri, Kahramanmaraş, Türkiye 


\section{INTRODUCTION}

The genus Astragalus L. (Leguminosae; Fabaceae) is one of the largest genera of the vascular plants in the world and distributed mainly around semi-arid steppe regions (Chamberlain and Matthews, 1970; Davis et al., 1988; Frodin, 2004). It is represented by approximately over 3000 taxa in the Old and New World. The New World representatives (= species from those of American) of Astragalus has almost 550 species, whereas the Old World (= species from those of Asiatic) representatives of the species-rich genus Astragalus has almost 2500 species (Podlech \& Zarre 2013) (Figure 1).

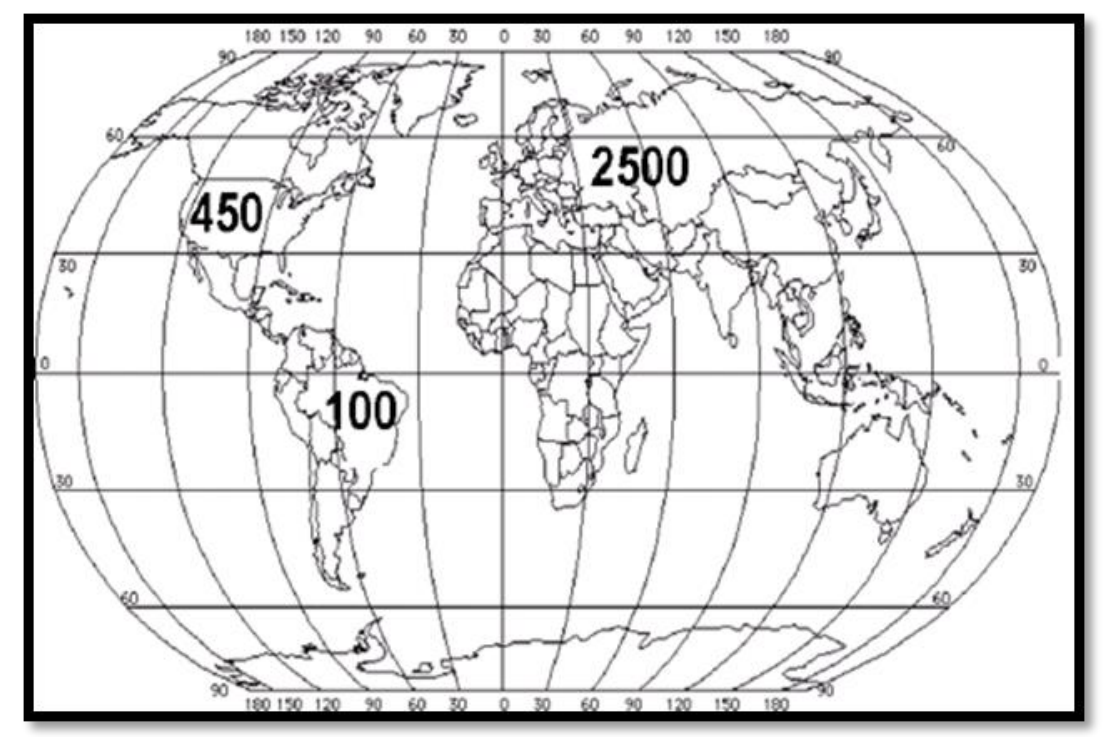

Figure 1. Major centres of distribution of Astragalus in the World (Podlech \& Zarre 2013)

In addition, the genus is very important in terms of biodiversity. Major areas of species endemism for this genus occur in Turkey, Iran, Kazakhstan, Afghanistan and China (Ghahreman et al. 2002; Podlech 2001; Mahmoodi et al. 2012). In accordance with the diversity centres of the genus Astragalus, while Turkey (with ca. 466 taxa including subspecies and varieties and endemism rate of $47 \%$ according to Ekici et al. 2015) is found in front of China (with 388 taxa, endemism 54\% according to Wei \& Ping 2010), it comes immediately after Iran (with 800 taxa, endemism nearly 50\% according to Maassoumi 2005).

The genus Astragalus is the largest genus in Turkey and classified in 63 sections and the sect. Rhacophorus is the richest one with almost 70 taxa (Aytaç et al. 2012). This is also the most species rich genus in Iran, and sect. Hymenostegis (with ca. 44 species) is one of its largest sections in Iran (Podlech et al. 2010). Most species grow in semi-arid and arid areas throughout the world, but a few species prefer humid habitats as stressed by Zarre \& Azani (2012). Kahramanmaraş is also on the route of semi-arid steppe region, so it has diverse taxonomical richness of Astragalus.

The ecological traits and usages of Astragalus are little known in Turkey, although there are many species. The members of the genus prevent erosion with the deep roots and wide branches covering the soil surface. The roots can reach quite deep and serve as a guard against the sliding of soils. They can also live in all kinds of soil and in severe climatic conditions, so they are important for soil conservation (Kadığlu et al. 2008). Most species of 
the genus have cluster-shaped cushion forms that they are often thorny perennial herbaceous plants as compatible with harsh climates (Aytaç et al. 2012).

This genus is also notable for its "gum". Some pharmacological and physiological actions of Astragalus with its dried roots and gum tragacanth as followed: anti-inflammatory, antiphlegmatic, anti-septic, anti-viral, anti-aging, anti-diabetic, anti-oxidative, anti-tumor, cardioprotection, hepato-protective, neuron-protective, carminative, demulcent, desiccative, fattening, glutinous, laxative, refrigerant, resolvent and styptic (Li et al. 2014; Lysiuk \& Darmohray 2016). Flowers of Astragalus serve as main source to honey-bees for making honey. Bees make honey from the nectar of flowers. Especially in Şemdinli honey, which is very famous in Turkey. Smell, unique taste and quality are derived from flowers of milkvetch species in the region like Anzer honey from Rize province of Turkey (Karaköse et al. 2018).

Nowadays, because of the rapid increase in technology, using the applications of Geographical Information Systems are increasing steadily. This technology is effective in providing multi-dimensional analysis, time-saving, more accurate results and visual assessment. GIS and its components have become an indispensable tool for spatial inquiry, database creation, managing this database and planning to do things easily. GIS has methods and techniques to determine the spatial data numerically and to work with the data obtained, to save the data in different formats and to perform the subtraction operations on the recorded data, to analyse and model these data and to graph them (Fisher \& Nijkamp 1992; Goodchild et al. 1992). Therefore, in this study, it is aimed to transfer the location information of Astragalus taxa in Kahramanmaraş province to digital geographic database to create a dataset. Spatial analyses were also performed from the dataset.

\section{MATERIAL AND METHOD}

Dataset has been compiled mainly using "Flora of Turkey and the East Aegean Islands" (Davis 1965-85; Davis et al. 1988; Güner et al. 2000) together with the regional floras (Duman \& Aytaç 1994; Kara 1995; Karakısa 1997; Varol 1997; Yıldız 2001; Varol \& Tatl1 2003; Aytaç \& Duman 2005; Başaran 2006; Çenet et al. 2006; Akkaya 2007; İlçim et al. 2008a; Uygun 2014; Kocabaş et al. 2014), vegetation studies (Duman 1985, 1990; Varol \& Tatl1 2003; Tel et al. 2018), check lists (Özhatay \& Kültür, 2006; Özhatay et al. 2009, 2011, 2013, 2015, 2018), published papers (Duman et al, 1995; Ekici \& Aytaç 2001; İlçim et al. 2008b; Podlech \& Ekici 2008; Taeb \& Uzunhisarcıkl1 2012), new records (Duman \& Aytaç 1995; Varol et al. 1998), revision works (Aytaç 1997; Ekici \& Ekim 2004; Akan \& Aytaç 2014; Ekici et al. 2015) and recently collected plants by the authors of this present study pertinent with the flora of Kahramanmarass. Collected plant samples were deposited at Herbarium of Kahramanmaraş Sütçü İmam University, Faculty of Forestry (KASOF). For reassessing the IUCN threat categories, Red Data Book of Turkish Plants (Ekim et al. 2000; IUCN 2001) and several papers such as Ekici (2010) and Kandemir et al. (2015) were consulted. Updated plant list and photos of some species are presented in the appendix. In order to avoid repetitions, the numbers on the photos are associated with the numbers in the plant list.

\section{Preparation of the grid system map for the plant species distribution pattern}

Since the plant species localities in the references were not specified as coordinates, the locations were processed using the WGS84 coordinate system using the Google Earth 
program. These coordinates were then entered into Arc-GIS and created a point layer. In this study, since plant locations were coordinated by using Google Earth program, digitization was done by using the boundaries in Google Earth program for Kahramanmaraş province and the district boundaries. For the spatial analysis of the plants whose coordinates are processed, the grid system was applied within the provincial boundary. Due to its suitability for our study, a $10 \mathrm{~km} \times 10 \mathrm{~km}$ grid system has been prepared. This is done by using the Create fishnet feature in the data management tools section of the Arc-Toolbox window using ArcGIS 10.3 software (ESRI 2011) (Figure 2).

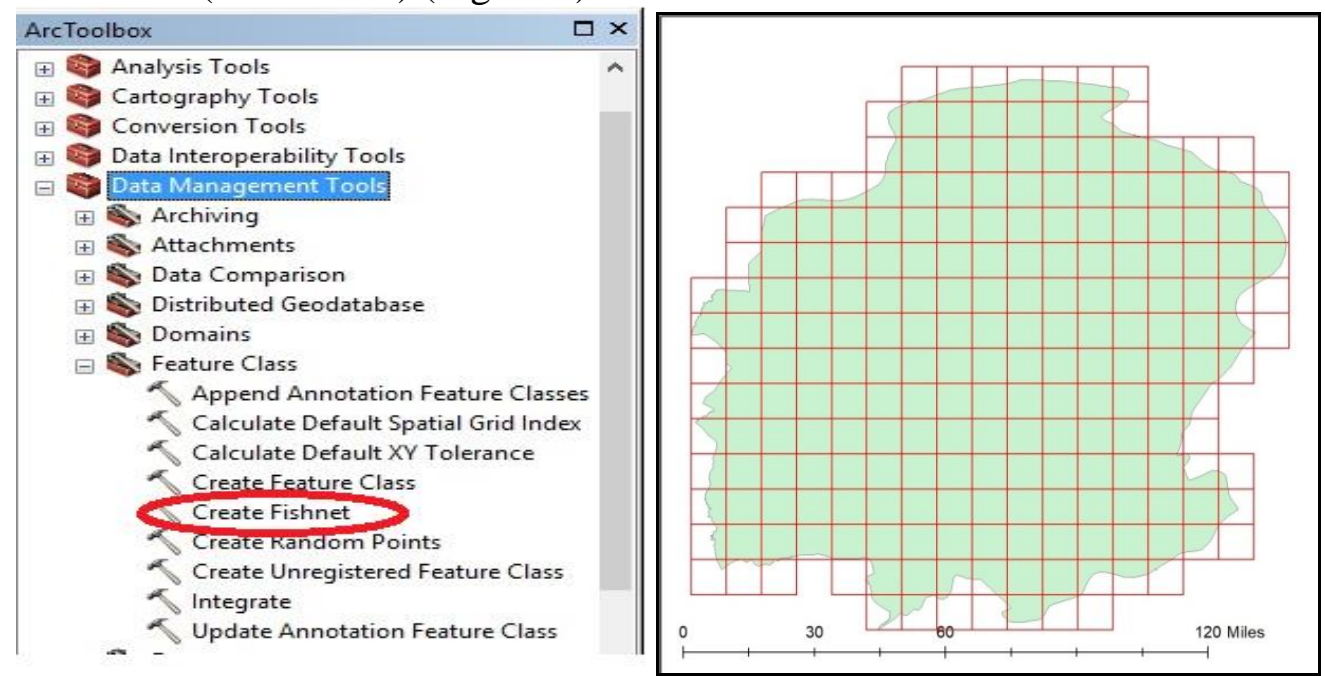

Figure 2. Arc-GIS menu used and $10 \mathrm{~km}$ x $10 \mathrm{~km}$ grid system

\section{RESULTS AND DISCUSSION}

According to the database, 95 Astragalus taxa whose valid names are investigated using Güner et al. (2012), are listed for the province of Kahramanmaraş. This number constitutes $20 \%$ of the total Astragalus taxa (one fifth of the total number) in Turkey. Totally, 37 Astragalus taxa (39\%) are endemic for Kahramanmaraş (Figure 3). Nine (9) of them (which indicated with asterisk in the appendix) are unique to this province.

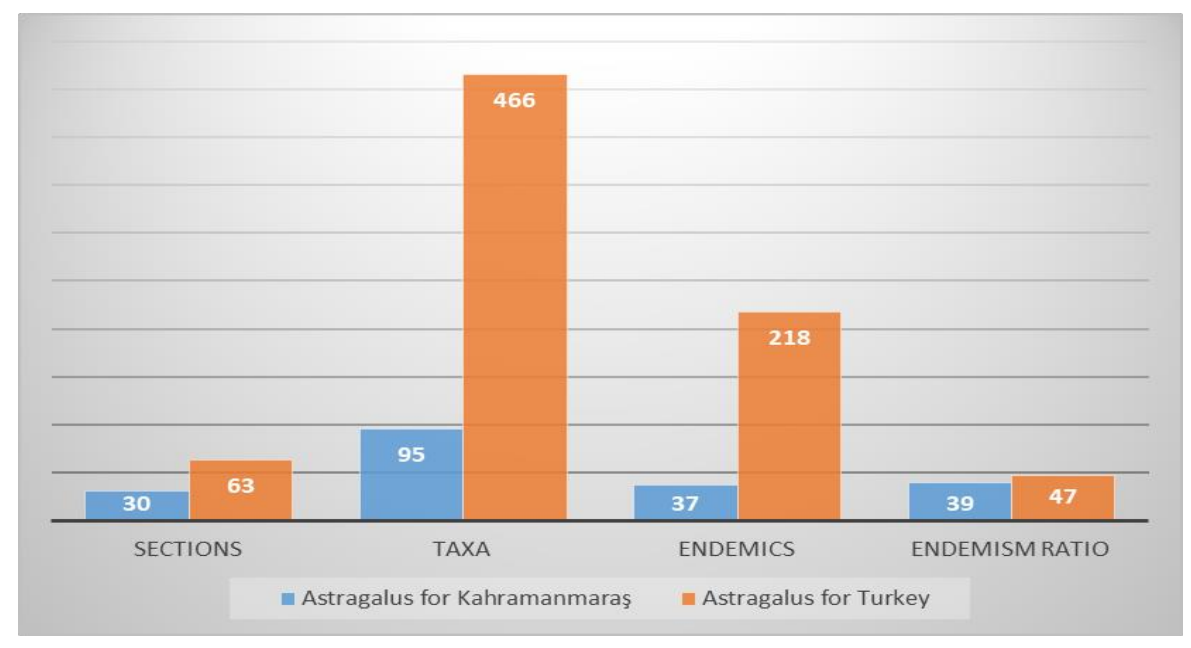

Figure 3. Comparison of Kahramanmaraş with Turkey in terms of the number of taxa. 
Astragalus taxa are represented by 30 sections in Kahramanmaraş. This number constitutes almost half $(48 \%)$ of the total sections in Turkey. Within the plant list, the largest sections are Sect. Rhacophorus with 23 taxa (from 49 for Turkey), Sect. Onobrychoidei with 8 taxa (from 31), Sect. Dasyphyllium with 6 taxa (from 14), Malacothrix with 6 taxa (from 10), Sect. Myobroma with 6 taxa (from 13), Sect. Proselius with 6 taxa (from 22) and Sect. Pterophorus with 6 taxa (from 22), and the remaining sections have less than 4 taxa for each (Figure 4).
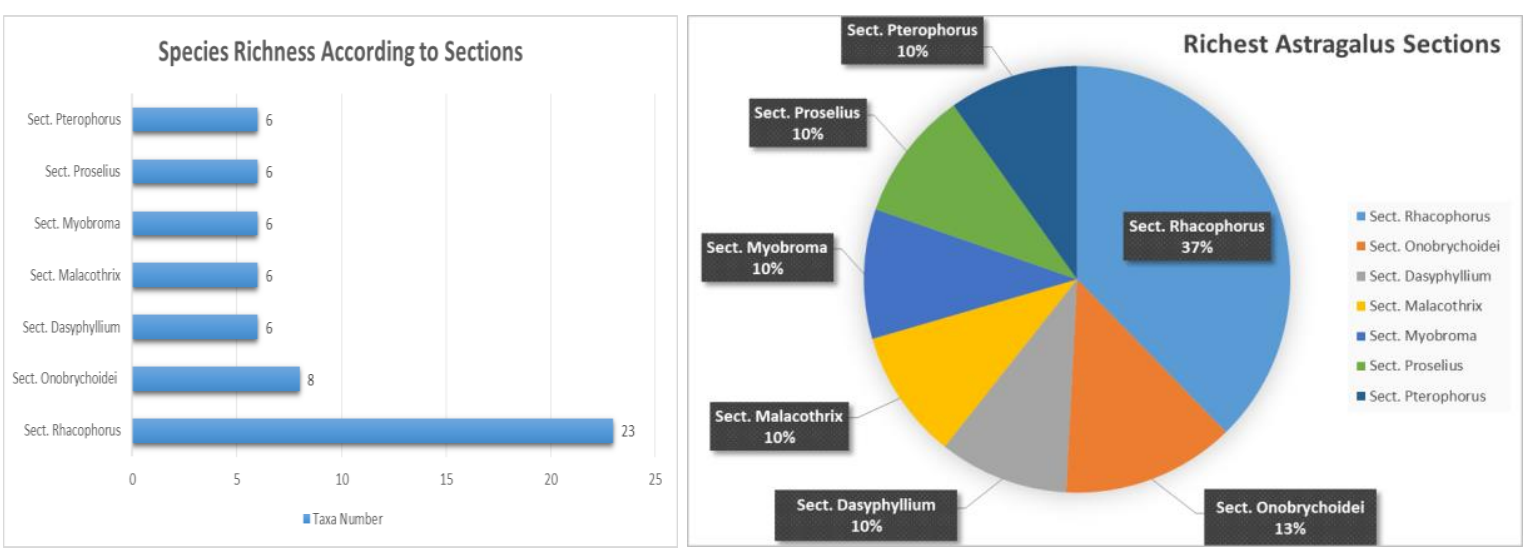

Figure 4. Richest Astragalus sections in Kahramanmaraş

The distribution of phytogeographical elements of the Astragalus taxa in the plant list; $59 \%$ (56 taxa) for Irano-Turanian elements, $30 \%$ (28 taxa) for Multi-regional or unknown and the remaining; $6 \%$ (6 taxa) for East Medit. element, $4 \%$ (4 taxa) East Medit. (mt.) element and 1 $\%$ (1 taxon) Euro-Siberian element (Table 1, Figure 5).

Table 1. The distribution of phytogeographical elements of the Astragalus taxa

\begin{tabular}{rcccc}
\hline & \multicolumn{2}{c}{ Kahramanmaraş } & \multicolumn{2}{c}{ Turkey } \\
\hline & Taxa Number & Ratio $(\%)$ & Taxa Number & Ratio (\%) \\
\hline Irano-Turanian element & $\mathbf{5 6}$ & 58.9 & $\mathbf{2 3 6}$ & 50.6 \\
\hline Multi regional or unknown & $\mathbf{2 8}$ & 29.5 & $\mathbf{1 7 2}$ & 36.9 \\
\hline East Medit. element & $\mathbf{6}$ & 6.3 & $\mathbf{2 7}$ & 5.8 \\
\hline East Medit. (mt.) element & $\mathbf{4}$ & 4.2 & $\mathbf{7}$ & 1.5 \\
\hline Euro-Siberian element & $\mathbf{1}$ & 1.1 & $\mathbf{4}$ & 0.9 \\
\hline Mediterranean element & 0 & 0.0 & $\mathbf{7}$ & 1.5 \\
\hline Euxine element & 0 & 0.0 & $\mathbf{7}$ & 1.5 \\
\hline Euxine (mt.) element & 0 & 0.0 & $\mathbf{6}$ & 1.3 \\
\hline Total & $\mathbf{9 5}$ & $\mathbf{1 0 0 . 0}$ & $\mathbf{4 6 6}$ & $\mathbf{1 0 0 . 0}$ \\
\hline
\end{tabular}




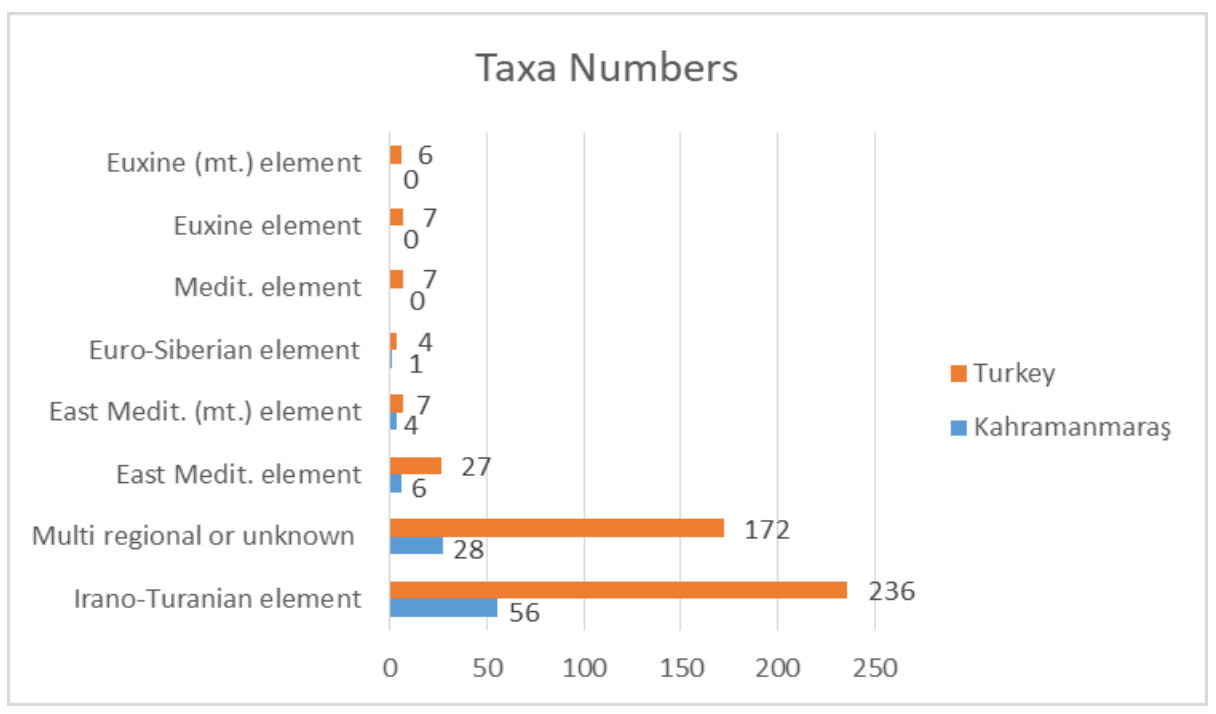

Figure 5. Phytogeographical elements

According to distributions, squares (J13) in Çağlayancerit, (D4, E4 and G8) in Göksun, (I10) between Ekinözü and central district, and (K10) in the central district of Kahramanmaraş are the richest squares in accordance with the taxa numbers (Figure 6). These areas are important in terms of conservation biology as they are the most intense areas of steppic conditions, livestock and grazing pressure. In addition, these areas are the highest mountain series (Binboğa, Berit, Koç, Ahir and Engizek Mountains) forming the roof of the province.

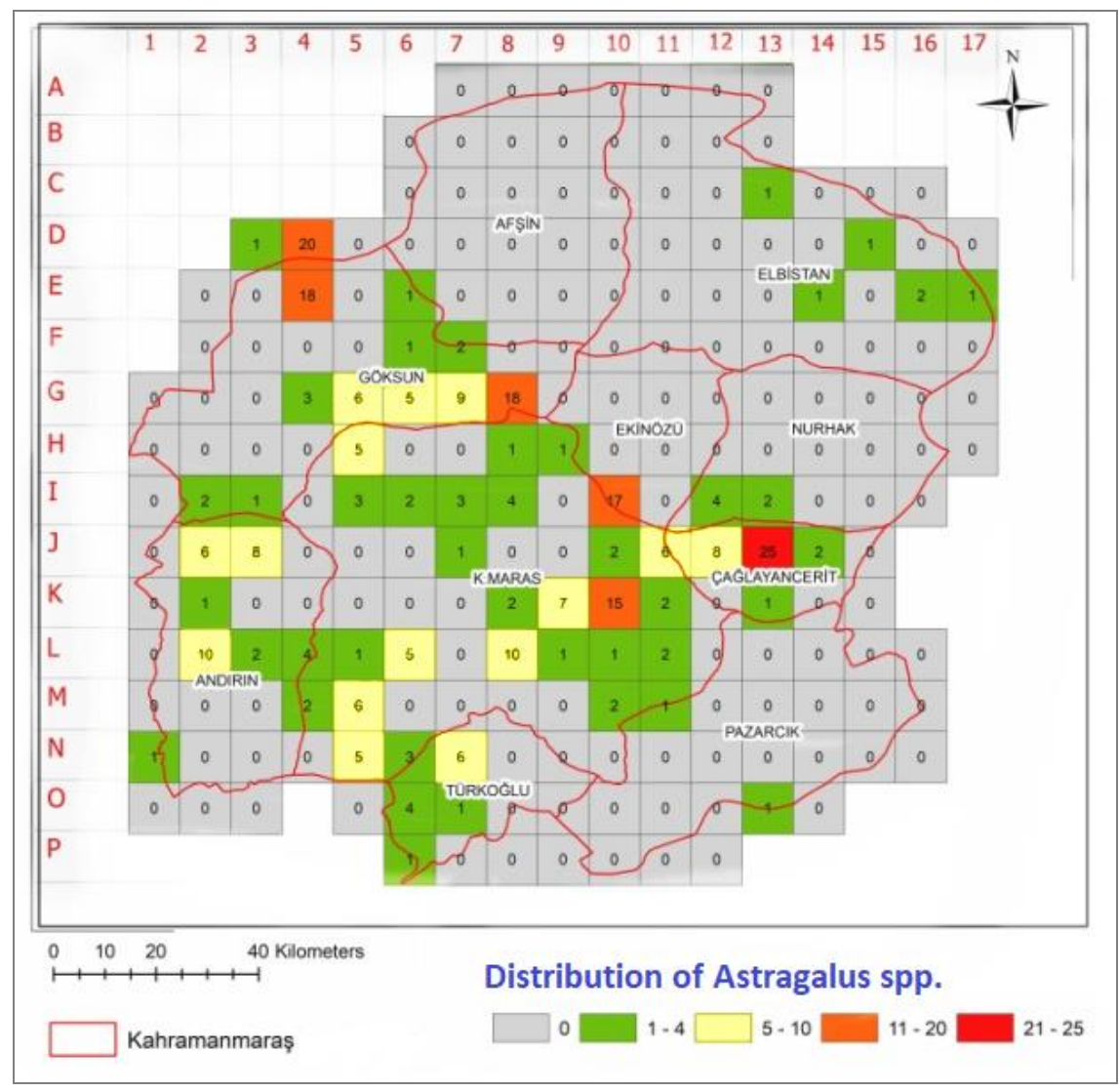

Figure 6. Distribution of Astragalus species in Kahramanmaraş 


\section{Endemism and Red List Assessment}

Totally 37 Astragalus taxa (39\%) are endemic to Kahramanmaraş province (Ekim et al. 2000; IUCN 2001). Eleven (11) of the total number of taxa are in threatened categories (CR, EN, VU). As a result, 4 endemic Astragalus taxa (A. akmanii Aytaç \& H. Duman, A. argentophyllus Taeb \& Uzunh., A. dumanii M. Ekici \& Aytaç and A. ekimii Zarre \& H. Duman) are in Critically Endangered (CR) category, 2 endemic taxa (A. distinctissimus Rech.f. \& Edelb. and A. lineatus Lam. var. bibracteolatus H. Duman \& Vural) are in Endangered (EN) category, 5 endemic taxa (A. aintabicus Boiss., A. macrouroides Hub.Mor., A. melitenensis Boiss., A. talasseus Boiss. \& Balansa, A. zahlbruckneri Hand.-Mazz.) are in Vulnerable (VU) category, while 11 endemic taxa in Near Threatened (NT) and 15 endemic taxa are in Least Concern (LC) threat category (Table 2, Figure 7).

Table 2. Comparison of IUCN threat categories of Astragalus spp.

\begin{tabular}{|c|c|c|c|c|}
\hline & \multicolumn{2}{|c|}{ Kahramanmaraş } & \multicolumn{2}{c|}{ Turkey } \\
\hline & Taxa Number & Ratio (\%) & Taxa Number & Ratio (\%) \\
\hline EX & 0 & 0.0 & 1 & 0.5 \\
\hline CR & 4 & 10.8 & 33 & 15.1 \\
\hline EN & 2 & 5.4 & 35 & 16.1 \\
\hline VU & 5 & 13.5 & 49 & 22.5 \\
\hline NT & 11 & 29.7 & 37 & 17.0 \\
\hline LC & 15 & 40.5 & 44 & 20.2 \\
\hline DD & 0 & 0.0 & 19 & 8.7 \\
\hline Total & 37 & 100.0 & 218 & 100.0 \\
\hline
\end{tabular}
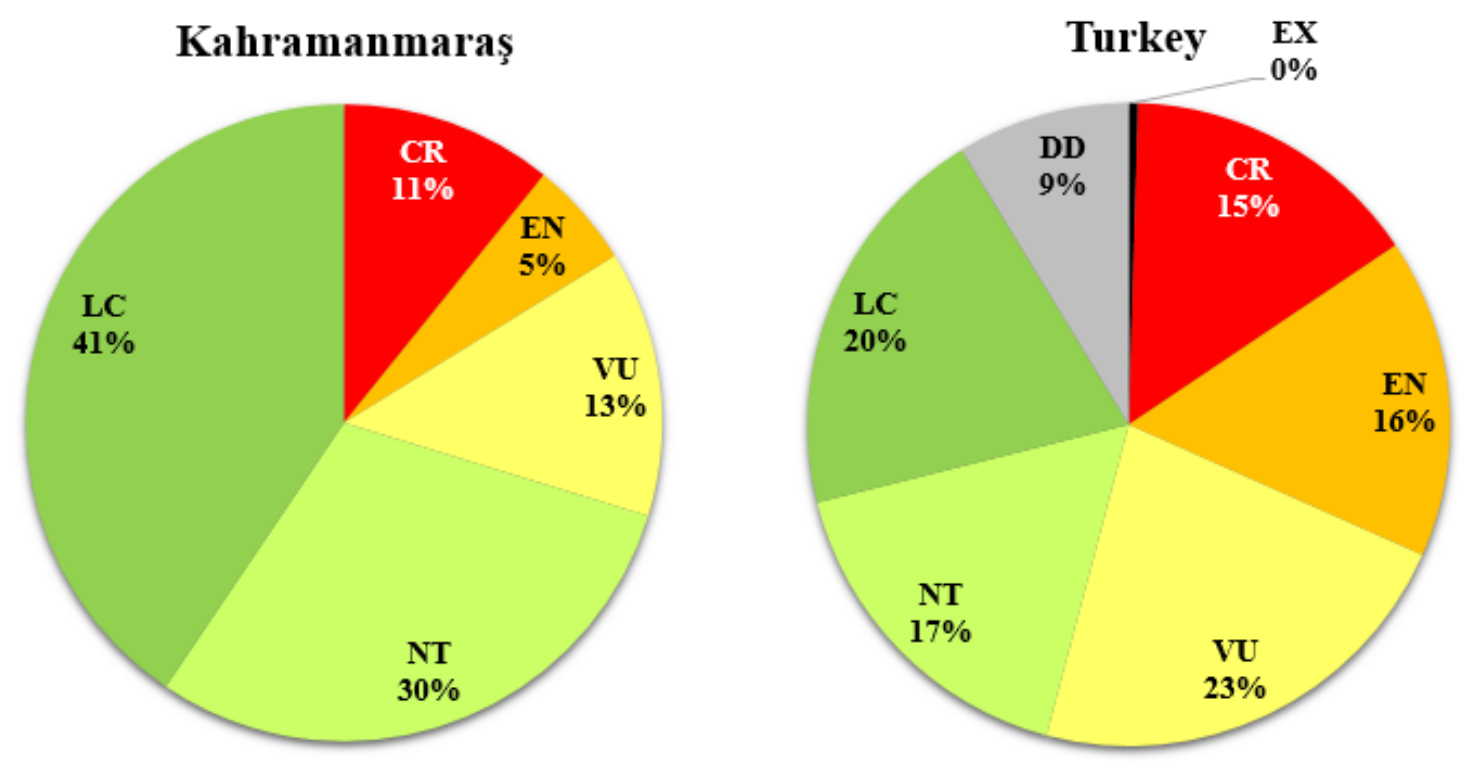

Figure 7. Comparison of IUCN threat categories of studied Astragalus spp.

Previous taxonomic studies related to flora of Kahramanmaraş have resulted with the discoveries of some new Astragalus species (such as A. dumanii M. Ekici \& Aytaç, A. akmanii Aytaç \& H. Duman, A. ekimii Zarre \& H.Duman and Astragalus lineatus var. 
bibracteolatus H. Duman \& Vural) and new some distributions (Duman et al. 1995; Zarre \& Duman 1998; Ekici \& Aytaç 2001). With this present study, we also confirmed that Astragalus chamaphaca Freyn and Astragalus podperae Širj. have local distribution in Kahramanmaraş (Göksun).

Previous taxa names which are considered as synonyms were given as follows; Astragalus psilacmos Bunge, Astragalus andrachnifolius var. grandiflorus Eig, Astragalus tuna-ekimii N. Adigüzel, Astragalus sericans Freyn \& Sint., Astragalus macroscepus Boiss., Astragalus eriophyllus Boiss., Astragalus berytius Bunge, Astragalus glycyphyllos L. subsp. glycyphylloides (DC.) Matthews, Astragalus elbistanicus Hub.- Mor. \& D.F.Chamb., Astragalus kurdicus var. muschianus (Kotschy \& Boiss.) D.F.Chamb., Astragalus campylosema subsp. campylosema Boiss., Astragalus fodinarum Boiss. \& Noë ex Bunge, Astragalus ramicaudex D.F.Chamb., Astragalus plumosus var. akardaghicus (Eig) D.F.Chamb. \& V.A.Matthews, Astragalus plumosus var. krugianus (Freyn \& Bornm.) Chamb. \& Matthews, Astragalus pycnocephalus var. seytunensis (Bunde) Chamb., Astragalus suberosus subsp. ancyleus (Boiss.) V.A.Matthews, Astragalus xylobasis var. angustus (Freyn \& Sint.) Freyn \& Bornm. The valid names of these old names are listed in the appendix.

\section{CONCLUSIONS}

Kahramanmaraş (in Turkey) has a very rich plant biodiversity because of its different climatic zones over the rough and mountainous terrains. Existing biodiversity needs to be protected. In order to protect the plant species resources, planning and management are necessary. Considering the benefits and facilities of the GIS mentioned above, it is appropriate to use it in planning methods to protect biodiversity. It is possible to perform an in-depth analysis by combining several data layers with GIS. For example, when planning a conservation plan for an endangered plant, it is not enough to know the botanical characteristics of a current plant species. Therefore, a more accurate result will be obtained if a conservation plan is made by adding such ecological characteristics (temperature, precipitation and soil), spatial information and threats to the endangered plants. As a result, using GIS, a multidimensional analysis can be performed by adding more data layers in a targeted study. Furthermore, it is recommended that local establishments take care of areas with endemic plant density especially in their planning.

\section{ACKNOWLEDGEMENT}

In this study, we thank the scientists who contributed to the flora studies that constitute a part of the plant dataset. We would also like to thank (Professors) Dr. Zeki Aytaç, Dr. Murat Ekici and Dr. Hayri Duman (Gazi Univ.) for their kind help in identification of some Astragalus plant specimens. 


\section{REFERENCES}

Akan, H. \& Aytaç, Z. (2014). The revision of the section Alopecuroidei of the genus Astragalus (Fabaceae) in Turkey. Turk J Bot 38: 37-59.

Akkaya, B.O. (2007). Narlı (Kahramanmaraş)-Aşağımülk (Gaziantep) arasında kalan bölgenin floristik yönden incelenmesi (Yüksek Lisans Tezi), Kahramanmaraş Sütçü İmam Üniversitesi, Kahramanmaraş, Türkiye.

Aytaç, Z. (1997). The Revision of the section Dasyphyllium Bunge of the genus Astragalus L. of Turkey. Turk J Bot 21: 31-57.

Aytaç, Z. \& Duman, H. (2005). The steppic flora of high Mounts Ahir, Öksüz and Binboğa (Kahramanmaraş - Kayseri, Turkey). Fl. Medit. 15: 121-178.

Aytaç, Z., Ekici, M., Akan, H. (2012). Astragalus L. In: Güner A, Aslan S, Ekim T, Vural M, Babaç MT, editors. Türkiye Bitkileri Listesi (Damarlı Bitkiler). İstanbul, Turkey: Nezahat Gökyiğit Botanic Garden and Floristics Research Society.

Başaran, H. (2006). Sekeroba-Türkoğlu arasında kalan bölgenin floristik yönden incelenmesi (Yüksek Lisans Tezi), Kahramanmaraş Sütçü İmam Üniversitesi, Kahramanmaraş, Türkiye.

Çenet, M. Aydoğdu, M., İlçim, A. \& Toroğlu, S. (2006). İmalı Deresi ve çevresindeki tepelerin florası (Türkoğlu-Kahramanmaraş), KSÜ Fen ve Mühendislik Dergisi 9(1): $1-11$.

Davis, P.H. (1965-85). Flora of Turkey and the East Aegean Islands, Vol I-IX., Edinburgh University Press, Edinburgh.

Davis, P.H., Mill, R.R. \& Tan, K. (1988). Flora of Turkey and the East Aegean Islands, Vol. $\mathrm{X}$, Supplement, Edinburgh University Press, Edinburgh.

Duman, H. (1985). Engizek Dağı (Kahramanmaraş) Vejetasyonu. Ankara, Turkish Journal of Botany 19:2, 179-212 s.

Duman, H. (1990). Engizek Dağı (Kahramanmaraş) Vejetasyonu. Doktora Tezi, Gazi Univ. Fen Bil. Enst, Ankara.

Duman H. \& Aytaç, Z. (1994), Ahır, Berit, Binboğa ve Öksüz Dağları (KahramanmaraşKayseri), Yüksek dağ flora ve vejetasyonu, TÜBİTAK (TBAG-940), Ankara, 186 s.

Duman, H. \& Aytaç, Z. (1995). New floristic records for the grid squares B6 and C6. Turk J Bot 19(6): 615-621.

Duman, H., Aytaç, Z. \& Vural, M. (1995). Two new taxa from South Anatolia, Turk J Bot 19: 477-479. 
Ekici, M. (2010). Astragalus L. (Fabaceae) cinsinin Hypoglottidei DC., Incani DC. ve Dissitiflori DC. seksiyonlarında yer alan tükenmiş (EX) ve yetersiz veri (DD) basamağında bulunan taksonlar ile ilgili veriler. SAÜ Fen Edebiyat Dergisi (1): 31-42.

Ekici, M., Akan, H. \& Aytaç, Z. (2015). Taxonomic revision of Astragalus L. section Onobrychoidei DC. (Fabaceae) in Turkey. Turk J Bot 39: 708-745.

Ekici M. \& Aytaç Z. (2001). Astragalus dumanii (Fabaceae), a new species from Anatolia, Turkey. Annales Botanici Fennici 38 (3): 171-174

Ekici, M. \& Ekim, T. (2004). Revision of the section Hololeuce Bunge of the genus Astragalus L. (Leguminosae) in Turkey. Turk J Bot 28: 307-347

Ekim, T., Koyuncu, M., Vural, M., Duman, H., Aytaç, Z. \& Adigüzel, N. (2000). Türkiye Bitkileri Kırmızı Kitabı (Red Data Book of Turkish Plants Pteridophyta and Spermatophyta), Barışcan Ofset, Ankara, 246 s.

ESRI. (2011). ArcGIS 10 Desktop uygulama dökümanı. Sinan Ofset Matbaacılık San.Tic.Ltd.Şti, Ankara, 187 s.

Fisher, M. \& Nijkamp, P. (1992). GIS and spatial modelling, EGIS '92 Conference Proceedings, pages: 214-225.

Frodin, D.G. (2004). History and concepts of big plant genera. Taxon, 53(3): 753-776.

Ghahreman, A., Maassoumi, A.A. \& Ghahremani-nejad, F. (2002). Astragalus tuyehensis (Fabaceae), a new species from Iran. Novon 12: 47-49.

Güner, A., Özhatay, N., Ekim, T. \& Başer, K.H.C. (2000). Flora of Turkey and the East Aegean Islands, Vol. XI, Supplement - II, Edinburgh University Press, Edinburgh.

Güner, A., Aslan, S., Ekim, T., Vural, M. \& Babaç, M.T. (edlr.), (2012). Türkiye Bitkileri Listesi (Damarlı Bitkiler), Nezahat Gökyiğit Botanik Bahçesi ve Flora Araştırmaları Derneği Yayını. İstanbul.

Goodchild, M., Haining, R. \& Wise, S. (1992). Integrating GIS and spatial data analysis, problems and possibilities. Int. J. Geographical Information Systems (6): 407-423.

IUCN, (2001). Red List Categories: Version 3.1. Prepared by the IUCN Species Survival Commission. Gland, Switzerland and, Cambridge.

İlçim, A, Kocabaş, Y. \& Başaran, H. (2008a). Şekeroba çevresinin (Kahramanmaraş) floristik yönden incelenmesi. KSÜ Doğa Bilimleri Dergisi 11: 13-22.

İlçim, A., Çenet, M. \& Dadand1, M.Y. (2008b). Stachys marashica (Lamiaceae), A new species from Turkey, Ann. Bot. Fennici, 45: 151-155.

Kara, C. (1995). Yukarı Ceyhan Vadisi florası (Kahramanmaraş). Dumlupınar Üniv., Fen Bil. Enst., Yüksek Lisans Tezi, Kütahya 2-28s. 
Kadığlu, B., Kadığlu, S., Turan, Y. (2008). Gevenlerin (Astragalus sp.) farklı kullanım alanları ve önemi. Alinteri Zirai Bilimler Dergisi 14(1): 17-26.

Kandemir, A., Sevindi, C., Korkmaz, M. \& Çelikoğlu, Ş. (2015). Erzincan (Türkiye)’a özgü endemik bitki taksonlarının IUCN tehdit kategorileri. Bağbahçe Bilim Dergisi 2 (1): 43-65.

Karakısa, İ. (1997). Dibek Dağları ve Çevresi (Kahramanmaraş) Florası üzerine bir ön araştırma, Yüksek Lisans Tezi, Yüzüncü Yıl Üniversitesi Fen Bilimleri Enstitüsü, Van, $140 \mathrm{~s}$.

Karaköse, M., Polat, R., Rahman, M.O. \& Çakilcioğlu, U. (2018). Traditional honey production and bee flora of Espiye, Turkey. Bangladesh J. Plant Taxon. 25(1): 79-91.

Kocabaş, Y.Z., İlçim, A., Çömlekçioğlu, N. (2014). Kahramanmaraş Başkonuş Dağ1 gevenleri (Astragalus spp.) ve önemi. III. Uluslararası Odun Dış1 Orman Ürünleri Sempozyumu, 8-10 Mayıs 2014, Kahramanmaraş.

Li, X., Qu, L., Dong, Y., Han, L., Liu, E., Fang, S., Zhang, Y. \& Wang, T. (2014). A Review of recent research progress on the Astragalus genus. Molecules 19: 18850-18880.

Lysiuk, R. \& Darmohray, R. (2016). Pharmacology and ethnomedicine of the genus Astragalus. International Journal of Pharmacology, Phytochemistry and Ethnomedicine 3: 46-53.

Maassoumi A.A., (2005). The genus Astragalus in Iran, vol. 5. - Tehran: Research Institute of Forests and Rangelands.

Özhatay, N. \& Kültür, Ş. (2006). Check-list of additional taxa to the supplement flora of Turkey III. Turk J Bot 30: 281-316.

Özhatay, N., Kültür, Ş. \& Aslan, S. (2009). Check-list of additional taxa to the supplement flora of Turkey IV. Turk J Bot 33: 191-226.

Özhatay, F.N., Kültür, Ş. \& Gürdal, M.B. (2011). Check-list of additional taxa to the supplement flora of Turkey V. Turk J Bot 35: 589-624.

Özhatay, N., Kültür, Ş. \& Gürdal, B. (2013). Check-list of additional taxa to the supplement flora of Turkey VI. J Fac Pharm Istanbul 43(1): 33-82.

Özhatay, N., Kültür, Ş. \& Gürdal, B. (2015). Check-list of additional taxa to the supplement flora of Turkey VII. J Fac Pharm Istanbul 45(1): 61-86.

Podlech, D. (2001). Contribution to the knowledge of the genus Astragalus L. (Leguminosae) VII-X. Sendtnera 7: 163.

Podlech, D. \& Ekici, M. (2008). Some new and interesting Astragalus species (Fabaceae) from Turkey. Feddes Repert 119: 24-36. 
Podlech, D., Zarre, Sh., Massoumi A.A., Ekici, M., Sytin, A. (2010). Papilionaceae VI: Astragalus IV. In: Rechinger KH, editor. Flora Iranica. 178. Graz, Austria: Akad. Druck-u. Verlagsanst, pp. 58-146.

Podlech, D. \& Zarre, S.H. (2013). A Taxonomic revision of the genus Astragalus L. (Leguminosae) in the Old World, Vol. II, pp. 1039-1150. Vienna, Austria: Naturhistorisches Museum Wien.

Tel, A.Z., Ortaç, İ. \& İlçim, A. (2018). A Study on the flora of some natural and cultural sites of Kahramanmaraş province (Turkey). Comm. J. Biol. 2(2): 43-47.

Taeb, F. \& Uzunhisarcıkl1, M.E. (2012). Astragalus argentophyllus (Fabaceae), a new species from south Anatolia, Turkey. Annales Botanici Fennici 49(4): 259-262.

Uygun, C. (2014). Sarımsak, Tırıl ve Kayranlı Dağlarının (Andırın- Kahramanmaraş) florası (Doktora Tezi), Kahramanmaraş Sütçü İmam Üniversitesi, Kahramanmaraş, Türkiye.

Varol, Ö. (1997). Başkonuş Dağı (Kahramanmaraş) florası, Turkish Journal of Botany, 27: 117-139.

Varol, Ö., Çenet, M. \& İlçim, A. (1998). C6 karesinden yeni floristik kayıtlar. II. Uluslararası Kızılırmak Fen Bilimleri Kongresi. (20-22 Mayıs), Kırıkkale

Varol, Ö. \& Tatlı, A. (2003). Çimen Dağı (Kahramanmaraş)'nın floristik özellikleri, Ekoloji Çevre Dergisi 12(46): 17-28.

Wei, C. \& Ping, Y. (2010). Astragalus beitashanensis, a new species of Leguminosae from Xinjiang, China. NOVON 20: 21-22.

Yıldız, B. (2001). Berit Dağı'nın (Kahramanmaraş) floristik özellikleri, Turkish Journal of Botany, 25: 63-102.

Zarre, M.S. \& Duman H. (1998). Three new Tragacanthic species of the genus Astragalus (Fabaceae) from Turkey. Edinb. J. Bot. 55: 351-358. 
Appendix. (Plant list of Astragalus spp.)

\begin{tabular}{|c|c|c|c|c|c|c|}
\hline No & Sections & Scientific name & Endemism & IUCN & Floristic region & Determined via \\
\hline 01 & Onobrychium & Astragalus aduncus Willd. & - & - & Irano-Turanian & literature / field work \\
\hline $\mathbf{0 2}$ & Rhacophorus & Astragalus aintabicus Boiss. & end. & VU & $\begin{array}{l}\text { Multi regional or } \\
\text { unknown }\end{array}$ & literature \\
\hline $\mathbf{0 3}$ & Hypoglottidei & Astragalus akmanii Aytaç \& H. Duman & $*_{\text {end }}$ & CR & $\begin{array}{l}\text { Multi regional or } \\
\text { unknown }\end{array}$ & literature \\
\hline 04 & Rhacophorus & $\begin{array}{l}\text { Astragalus amblolepis (Fisch.) Podlech } \\
\text { (syn: Astragalus psilacmos Bunge) }\end{array}$ & - & - & Irano-Turanian & literature / field work \\
\hline $\mathbf{0 5}$ & Myobroma & Astragalus angustiflorus subsp. amanus (Boiss.) D.F.Chamb. & end. & NT & East Medit. & literature / field work \\
\hline 06 & Melanocercis & Astragalus angustifolius subsp. angustifolius Lam. & - & - & $\begin{array}{l}\text { Multi regional or } \\
\text { unknown }\end{array}$ & literature / field work \\
\hline 07 & Melanocercis & Astragalus angustifolius subsp. pungens (Willd.) Hayek & - & - & $\begin{array}{l}\text { Multi regional or } \\
\text { unknown }\end{array}$ & literature \\
\hline 08 & Malacothrix & Astragalus argentophyllus Taeb \& Uzunh. & *end. & CR & Irano-Turanian & literature \\
\hline 09 & Onobrychium & Astragalus asciocalyx Bunge & - & - & Irano-Turanian & literature \\
\hline 10 & Rhacophorus & Astragalus barbeyanus Post & - & - & East Medit. (mt) & literature \\
\hline 11 & Brachycalyx & Astragalus brachycalyx Fisch. ex Boiss. & - & - & Irano-Turanian & literature \\
\hline 12 & Pterophorus & Astragalus brachypterus Fisch. & - & - & Irano-Turanian & literature / field work \\
\hline 13 & Myobroma & Astragalus brachystachys DC. & - & - & Irano-Turanian & literature \\
\hline 14 & Onobrychium & Astragalus cadmicus Boiss. & end. & $\mathbf{L C}$ & $\begin{array}{l}\text { Multi regional or } \\
\text { unknown }\end{array}$ & literature \\
\hline 15 & Christiana & Astragalus caraganae Fisch. \& C.A.Mey. & - & - & Irano-Turanian & literature \\
\hline 16 & Rhacophorus & $\begin{array}{l}\text { Astragalus cephalotes var. brevicalyx Eig } \\
\text { (syn: Astragalus andrachnifolius var. grandiflorus Eig) }\end{array}$ & - & - & $\begin{array}{l}\text { Multi regional or } \\
\text { unknown }\end{array}$ & literature \\
\hline 17 & Rhacophorus & Astragalus cephalotes var. cephalotes Banks \& Sol. & - & - & $\begin{array}{l}\text { Multi regional or } \\
\text { unknown }\end{array}$ & literature \\
\hline
\end{tabular}




\begin{tabular}{|c|c|c|c|c|c|c|}
\hline 18 & Macrosemium & $\begin{array}{l}\text { Astragalus chamaephaca Freyn } \\
\text { (syn: Astragalus tuna-ekimii N. Adıgüzel) }\end{array}$ & - & - & Irano-Turanian & literature / field work \\
\hline 19 & Christiana & $\begin{array}{l}\text { Astragalus christianus subsp. christianus L. } \\
\text { (syn: Astragalus sericans Freyn \& Sint.) }\end{array}$ & - & - & $\begin{array}{l}\text { Multi regional or } \\
\text { unknown }\end{array}$ & literature / field work \\
\hline 20 & Rhacophorus & Astragalus commagenicus (Hand.-Mazz.) Širj. & end. & LC & East Medit. (mt) & literature \\
\hline 21 & Pterophorus & Astragalus condensatus Ledeb. & end. & $\mathbf{L C}$ & Irano-Turanian & literature / field work \\
\hline 22 & Stereothrix & Astragalus coodei D.F.Chamb. \& V.A.Matthews & end. & $\mathbf{L C}$ & Irano-Turanian & literature \\
\hline 23 & Dasyphyllium & Astragalus cretaceus Boiss. & - & - & Irano-Turanian & literature \\
\hline 24 & Rhacophorus & Astragalus cuspistipulatus Eig & - & - & East Medit. & literature \\
\hline 25 & Pterophorus & Astragalus cymbibracteatus Hub.-Mor. \& D.F.Chamb. & end. & NT & Irano-Turanian & literature \\
\hline 26 & Rhacophorus & Astragalus cymbostegius Bunge & *end. & NT & East Medit. (mt) & literature \\
\hline 27 & Dasyphyllium & $\begin{array}{l}\text { Astragalus densifolius subsp. densifolius Lam. } \\
\text { (syn: Astragalus macroscepus Boiss., Astragalus eriophyllus Boiss.) }\end{array}$ & - & - & Irano-Turanian & literature / field work \\
\hline 28 & Tapinodes & Astragalus depressus var. depressus $\mathrm{L}$. & - & - & $\begin{array}{l}\text { Multi regional or } \\
\text { unknown }\end{array}$ & literature \\
\hline 29 & Rhacophorus & Astragalus diphtherites var. diphtherites Fenzl & - & - & Irano-Turanian & literature \\
\hline 30 & Macrophyllium & Astragalus dipodurus Bunge & - & - & Irano-Turanian & literature / field work \\
\hline 31 & Dasyphyllium & Astragalus distinctissimus Rech.f. \& Edelb. & end. & EN & East Medit. & literature \\
\hline 32 & Pterophorus & Astragalus drusorum Boiss. & - & - & $\begin{array}{l}\text { Multi regional or } \\
\text { unknown }\end{array}$ & literature \\
\hline 33 & Hololeuce & Astragalus dumanii M. Ekici \& Aytaç & *end. & CR & Irano-Turanian & literature \\
\hline 34 & Rhacophorus & Astragalus ekimii Zarre \& H.Duman & $*$ end. & CR & East Medit. (mt) & literature \\
\hline 35 & Proselius & Astragalus elongatus subsp. elongatus Willd. & - & - & Irano-Turanian & literature \\
\hline 36 & Proselius & Astragalus elongatus subsp. nucleiferus (Boiss.) D.F.Chamb. & - & - & $\begin{array}{l}\text { Multi regional or } \\
\text { unknown }\end{array}$ & literature / field work \\
\hline 37 & Dasyphyllium & $\begin{array}{l}\text { Astragalus emarginatus Labill. } \\
\text { (syn: Astragalus berytius Bunge) }\end{array}$ & - & - & Irano-Turanian & literature \\
\hline
\end{tabular}




\begin{tabular}{|c|c|c|c|c|c|c|}
\hline 38 & Acmothrix & Astragalus fragrans Willd. & - & - & $\begin{array}{l}\text { Multi regional or } \\
\text { unknown }\end{array}$ & literature \\
\hline 39 & Glycyphyllos & Astragalus fraxinifolius DC. & - & - & Irano-Turanian & literature \\
\hline 40 & Hololeuce & Astragalus globosus Vahl & end. & $\mathbf{L C}$ & Irano-Turanian & literature \\
\hline 41 & Glycyphyllos & $\begin{array}{l}\text { Astragalus glycyphylloides DC. } \\
\text { (syn: Astragalus glycyphyllos L. subsp. glycyphylloides (DC.) } \\
\text { Matthews) }\end{array}$ & - & - & Euro-Siberian & literature / field work \\
\hline 42 & Platonychium & Astragalus gummifer Labill. & - & - & Irano-Turanian & literature \\
\hline 43 & Buceras & Astragalus hamosus L. & - & - & $\begin{array}{c}\text { Multi regional or } \\
\text { unknown }\end{array}$ & literature \\
\hline 44 & Dasyphyllium & Astragalus haussknechtii Bunge & *end. & NT & Irano-Turanian & literature \\
\hline 45 & Rhacophorus & Astragalus hilaris Bunge & $*_{-}$ & - & $\begin{array}{l}\text { Multi regional or } \\
\text { unknown }\end{array}$ & literature / field work \\
\hline 46 & Hololeuce & Astragalus hirsutus Vahl & end. & $\mathbf{L C}$ & $\begin{array}{l}\text { Multi regional or } \\
\text { unknown }\end{array}$ & literature \\
\hline 47 & Onobrychium & Astragalus karamasicus Boiss. \& Balansa & end. & $\mathbf{L C}$ & Irano-Turanian & literature \\
\hline 48 & Rhacophorus & Astragalus kurdicus Boiss. & - & - & $\begin{array}{l}\text { Multi regional or } \\
\text { unknown }\end{array}$ & literature \\
\hline 49 & Rhacophorus & Astragalus lamarckii Boiss. & end. & $\mathbf{L C}$ & Irano-Turanian & literature \\
\hline 50 & Dasyphyllium & Astragalus lanatus Lab. & - & - & Irano-Turanian & literature \\
\hline 51 & Myobroma & Astragalus leporinus var. hirsutus (Post) D.F.Chamb. & $*$ end. & $\mathbf{L C}$ & Irano-Turanian & literature / field work \\
\hline 52 & Myobroma & Astragalus leporinus var. leporinus Boiss. & end. & LC & Irano-Turanian & literature \\
\hline 53 & Rhacophorus & $\begin{array}{l}\text { Astragalus leucomallophorus Bornm. \& Širj. } \\
\text { (syn: Astragalus elbistanicus Hub.- Mor. \& D.F.Chamb.) }\end{array}$ & end. & NT & Irano-Turanian & literature \\
\hline 54 & Grammocalyx & Astragalus lineatus var. bibracteolatus H. Duman et Vural & *end. & EN & Irano-Turanian & literature \\
\hline 55 & Grammocalyx & Astragalus lineatus var. lineatus Lam. & - & - & $\begin{array}{c}\text { Multi regional or } \\
\text { unknown }\end{array}$ & literature \\
\hline
\end{tabular}




\begin{tabular}{|c|c|c|c|c|c|c|}
\hline 56 & Grammocalyx & Astragalus lineatus var. longidens (Freyn) Matthews & - & - & Irano-Turanian & literature / field work \\
\hline 57 & Onobrychium & Astragalus lycius Boiss. & end. & NT & $\begin{array}{l}\text { Multi regional or } \\
\text { unknown }\end{array}$ & literature / field work \\
\hline 58 & Alopecias & Astragalus macrocephalus subsp. finitimus (Bunge) D.F.Chamb. & - & - & Irano-Turanian & literature / field work \\
\hline 59 & Alopecias & Astragalus macrocephalus subsp. macrocephalus Willd. & - & - & Irano-Turanian & literature \\
\hline 60 & Malacothrix & Astragalus macrostachys DC. & - & - & Irano-Turanian & literature \\
\hline 61 & Malacothrix & Astragalus macrouroides Hub.-Mor. & end. & $\mathbf{V U}$ & Irano-Turanian & literature \\
\hline 62 & Malacothrix & Astragalus macrourus Fisch. \& C.A.Mey. & - & - & $\begin{array}{l}\text { Multi regional or } \\
\text { unknown }\end{array}$ & literature \\
\hline 63 & Hypoglottidei & Astragalus melanocarpus Bunge & end. & NT & Irano-Turanian & literature \\
\hline 64 & Cystodes & Astragalus melanocephalus Boiss & - & - & $\begin{array}{l}\text { Multi regional or } \\
\text { unknown }\end{array}$ & literature \\
\hline 65 & Onobrychium & Astragalus melitenensis Boiss. & end. & VU & Irano-Turanian & literature \\
\hline 66 & Rhacophorus & Astragalus microcephalus Willd. & - & - & Irano-Turanian & literature \\
\hline 67 & Rhacophorus & Astragalus micropterus Fisch. & end. & LC & Irano-Turanian & literature \\
\hline 68 & Malacothrix & Astragalus mollis M.Bieb. & - & - & Irano-Turanian & literature \\
\hline 69 & Rhacophorus & $\begin{array}{l}\text { Astragalus muschianus Kotschy \& Boiss. ex Boiss. } \\
\text { (syn: Astragalus kurdicus var. muschianus (Kotschy \& Boiss.) } \\
\text { D.F.Chamb.) }\end{array}$ & - & - & Irano-Turanian & literature \\
\hline 70 & Stereothrix & Astragalus nanus DC. & - & - & $\begin{array}{c}\text { Multi regional or } \\
\text { unknown }\end{array}$ & literature \\
\hline 71 & Xiphidium & Astragalus nitens Boiss. \& Heldr. & - & - & Irano-Turanian & literature \\
\hline 72 & Euodmus & Astragalus odoratus Lam. & - & - & $\begin{array}{l}\text { Multi regional or } \\
\text { unknown }\end{array}$ & literature \\
\hline 73 & Onobrychium & Astragalus onobrychis L. & - & - & $\begin{array}{c}\text { Multi regional or } \\
\text { unknown }\end{array}$ & literature \\
\hline
\end{tabular}




\begin{tabular}{|c|c|c|c|c|c|c|}
\hline 74 & Omithopodium & Astragalus ornithopodioides Lam. & - & - & Irano-Turanian & literature \\
\hline 75 & Myobroma & Astragalus ovinus Boiss. & - & - & $\begin{array}{l}\text { Multi regional or } \\
\text { unknown }\end{array}$ & literature \\
\hline 76 & Sisyrophorus & Astragalus pelliger Fenzl & end. & $\mathbf{L C}$ & East Medit. & literature \\
\hline 77 & Proselius & $\begin{array}{l}\text { Astragalus pendulus DC. } \\
\text { (syn: Astragalus campylosema subsp. campylosema Boiss., } \\
\text { Astragalus fodinarum Boiss. \& Noë ex Bunge) }\end{array}$ & - & - & Irano-Turanian & literature / field work \\
\hline 78 & Rhacophorus & Astragalus pennatulus Huber-Mor. \& Chamberlain & end. & NT & Irano-Turanian & literature \\
\hline 79 & Rhacophorus & Astragalus pennatus subsp. pennatus Boiss. & *end. & NT & $\begin{array}{l}\text { Multi regional or } \\
\text { unknown }\end{array}$ & literature \\
\hline 80 & Myobroma & $\begin{array}{l}\text { Astragalus pinetorum subsp. pinetorum Boiss. } \\
\text { (syn: Astragalus ramicaudex D.F.Chamb.) }\end{array}$ & - & - & Irano-Turanian & literature \\
\hline 81 & Rhacophorus & $\begin{array}{l}\text { Astragalus plumosus Willd. } \\
\text { (syn: Astragalus plumosus var. akardaghicus (Eig) D.F.Chamb. \& } \\
\text { V.A.Matthews, Astragalus plumosus var. krugianus (Freyn \& } \\
\text { Bornm.) Chamb. \& Matthews) }\end{array}$ & - & - & Irano-Turanian & literature \\
\hline 82 & Pterophorus & Astragalus podperae Širj. & - & - & Irano-Turanian & field work \\
\hline 83 & Rhacophorus & $\begin{array}{l}\text { Astragalus pycnocephalus Fischer } \\
\text { (syn: Astragalus pycnocephalus var. seytunensis (Bunde) Chamb.) }\end{array}$ & - & - & Irano-Turanian & literature \\
\hline 84 & Proselius & Astragalus schizopterus Boiss. & - & - & East Medit. & literature / field work \\
\hline 85 & Rhacophorus & Astragalus schottianus Boiss. & end. & NT & Irano-Turanian & literature \\
\hline 86 & Proselius & Astragalus sigmoideus Bunge & end. & $\mathbf{L C}$ & $\begin{array}{l}\text { Multi regional or } \\
\text { unknown }\end{array}$ & literature \\
\hline 87 & Theiochrus & Astragalus siliquosus Boiss. & - & - & Irano-Turanian & literature \\
\hline 88 & Stereothrix & Astragalus sparsipilis Hub.-Mor. \& D.F.Chamb. & end. & NT & Irano-Turanian & literature / field work \\
\hline 89 & Proselius & Astragalus spruneri Boiss. & - & - & East Medit. & literature / field work \\
\hline 90 & Platyglottis & $\begin{array}{l}\text { Astragalus suberosus Banks \& Sol. } \\
\text { (syn: Astragalus suberosus subsp. ancyleus (Boiss.) V.A.Matthews) }\end{array}$ & - & - & $\begin{array}{l}\text { Multi regional or } \\
\text { unknown }\end{array}$ & literature \\
\hline
\end{tabular}




\begin{tabular}{|c|c|c|c|c|c|c|}
\hline 91 & Pterophorus & Astragalus talasseus Boiss. \& Balansa & end. & $\mathbf{V U}$ & Irano-Turanian & literature \\
\hline 92 & Malacothrix & Astragalus tauricolus Boiss. & end. & $\mathbf{L C}$ & Irano-Turanian & literature / field work \\
\hline 93 & Hymenocoleus & Astragalus vaginans DC. & end. & $\mathbf{L C}$ & $\begin{array}{c}\text { Multi regional or } \\
\text { unknown }\end{array}$ & literature \\
\hline 94 & Onobrychium & $\begin{array}{l}\text { Astragalus xylobasis Freyn \& Bornm. } \\
\text { (syn: Astragalus xylobasis var. angustus (Freyn \& Sint.) Freyn \& } \\
\text { Bornm.) }\end{array}$ & - & - & Irano-Turanian & literature \\
\hline 95 & Rhacophorus & Astragalus zahlbruckneri Hand.-Mazz. & end. & VU & Irano-Turanian & literature \\
\hline
\end{tabular}

* Holo-types are based on the collections in Kahramanmaraş 


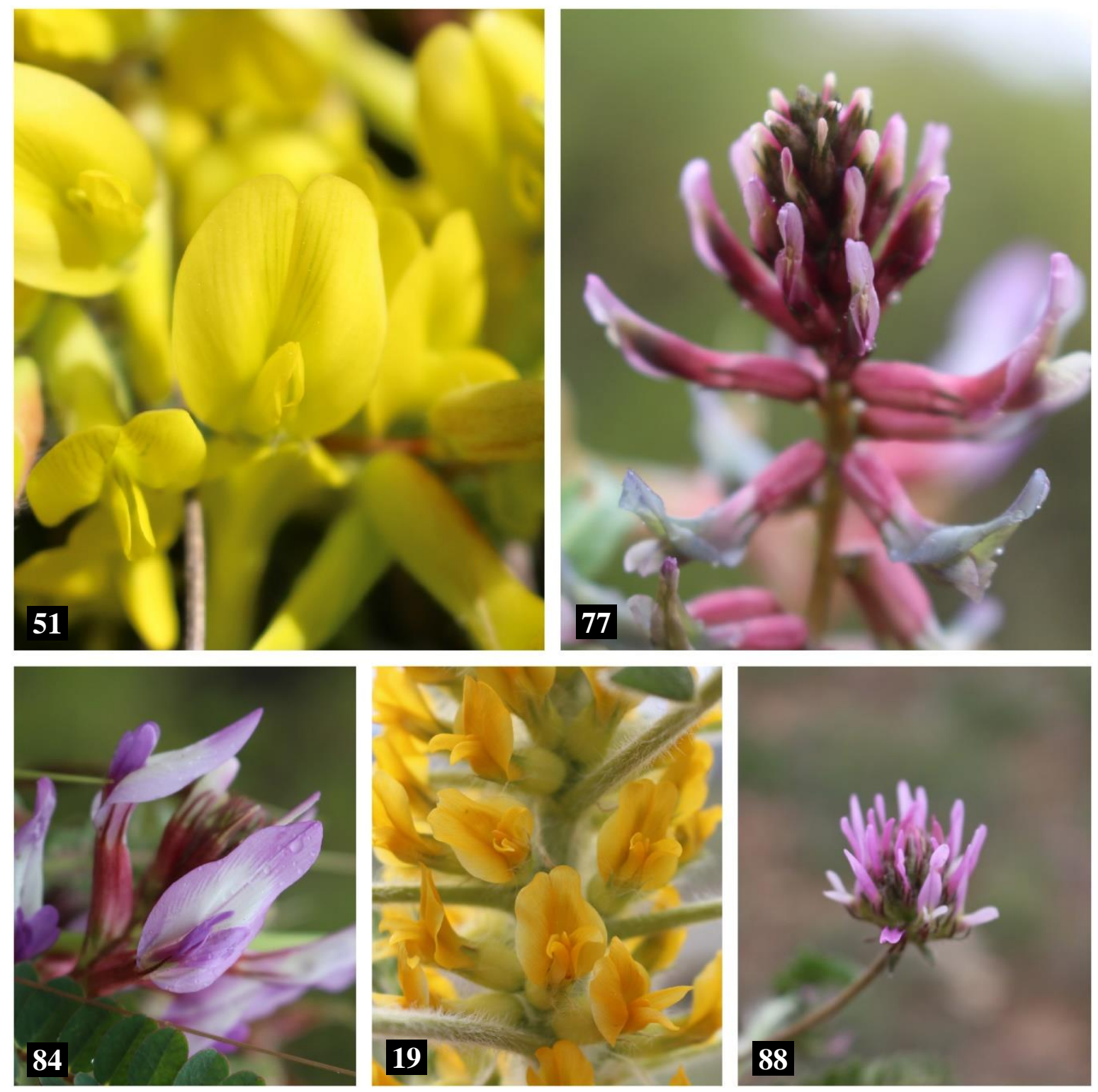



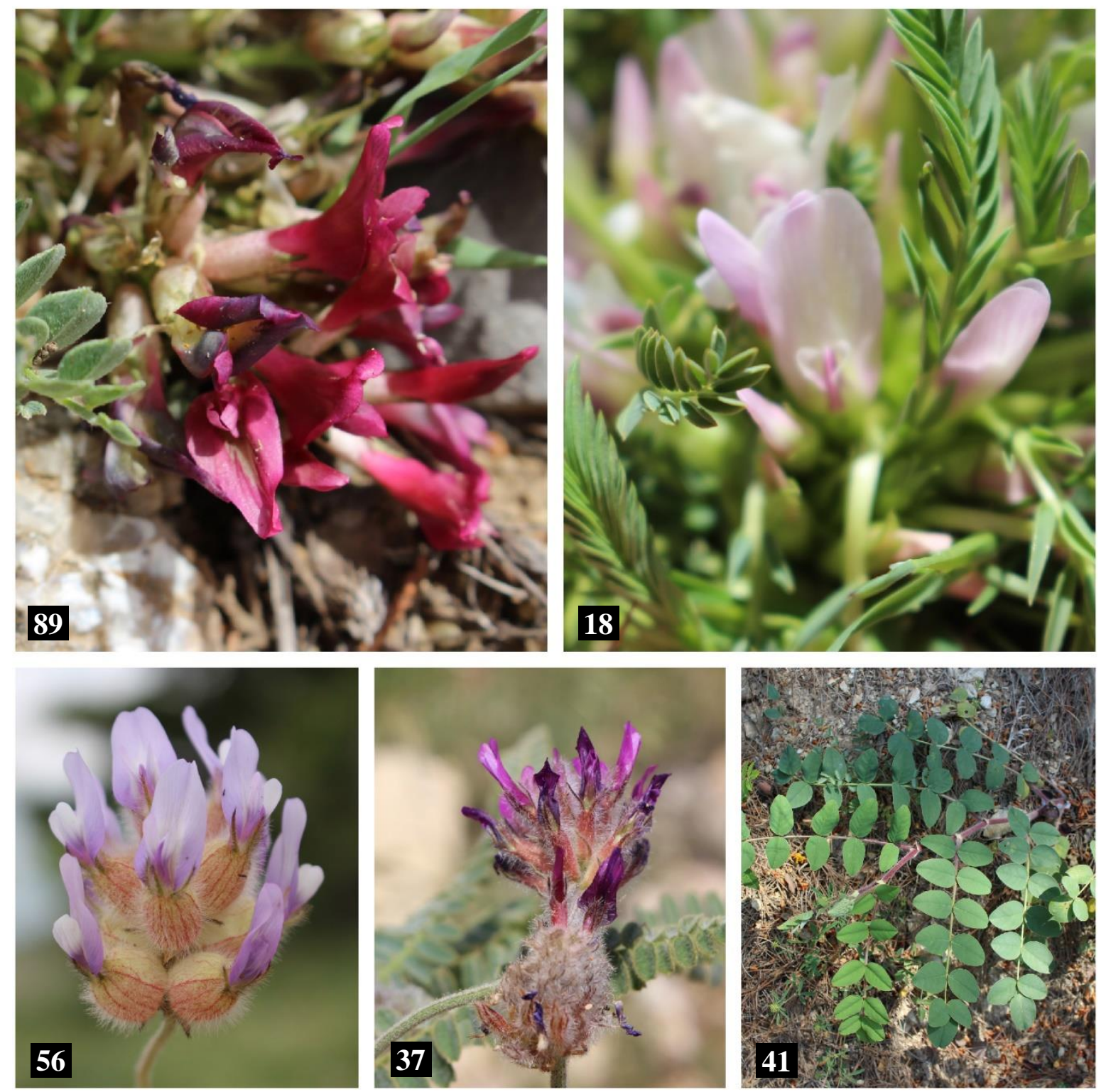

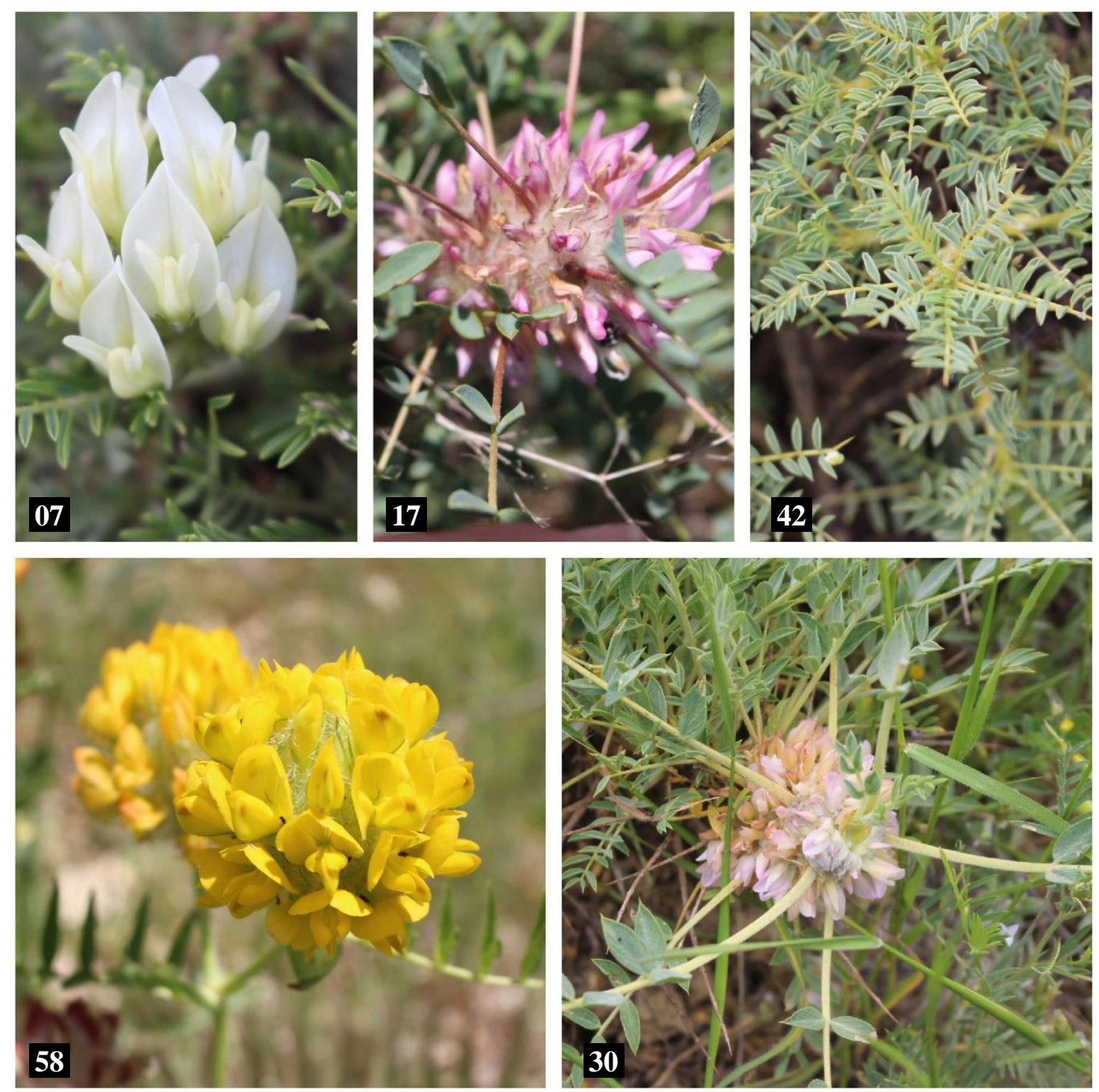

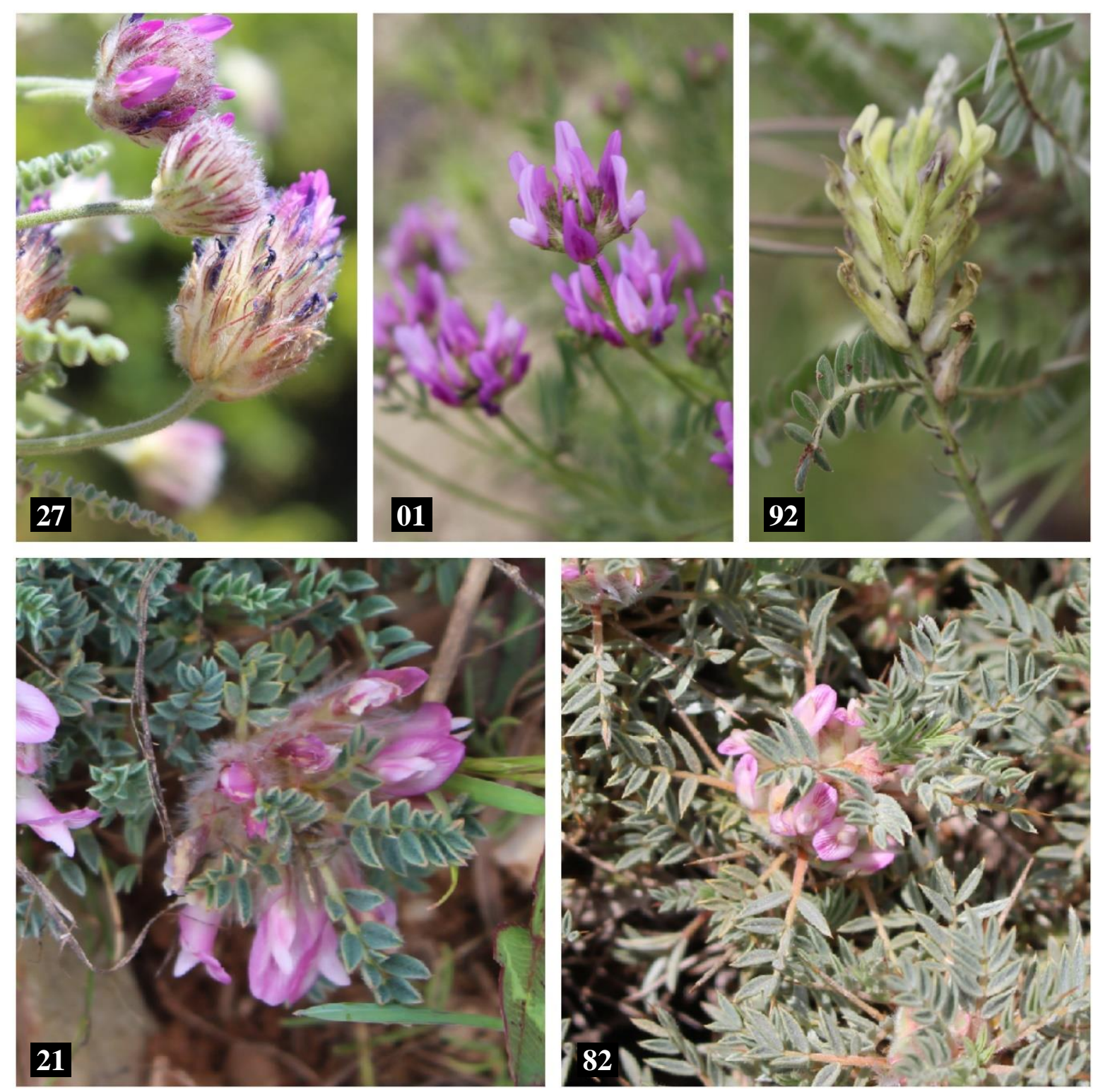